\title{
Criminal Law Policy Related to the Role of the Supervisory Board in the Review of Legislation No. 192019 about Changes to Two (2) of Law No. 30 of 2002 on the Corruption Eradication Commission (KPK)
}

\author{
Sahri $^{1}$, Mahmud Mulyadi ${ }^{2}$, Dedi Harianto ${ }^{3}$ \\ ${ }^{1}$ Master of Law Student, Universitas Muhammadiyah Sumatera Utara \\ ${ }^{2,3}$ Lecturer of Master of Law Universitas Muhammadiyah Sumatera Utara \\ Corresponding Author: Sahri
}

DOI: https://doi.org/10.52403/ijrr.20220242

\begin{abstract}
Corruption is a threat to democratic principles, as well as the security and stability of the nation of Indonesia. Institution established the Corruption Eradication Commission (KPK) has the task of conducting an investigation, investigation, prosecution of criminal acts of corruption. The board of Trustees was formed in order to carry out its function is to supervise the implementation of the duties and authority of the Commission. Regarding the duties of the Supervisory Board is to supervise the implementation of the duties and authority as at first, give permission or not to give permission tapping, shakedown, and/or seizure, after the decision of the Constitutional Court No. 70/PUU-XVII/2019, the authority of the Board of Trustees only as a watchdog and sets the code of ethics of the leadership and employees of the Commission KPK. The problem formulation in this research consists of: 1) What is the role of the Board of Trustees of the Corruption Eradication Commission (KPK) in the enforcement of the law against corruption? 2) How the position of the Supervisory Board in granting permission related to wiretapping, search and seizure in the institutions of the Corruption Eradication Commission (KPK) on the prevention and eradication of criminal acts of corruption after the decision of the Constitutional Court No. 70/PUU-XVII/2019? This research is a normative legal research with the approach of legislation (statute approach)
\end{abstract}

the assessment by using the technique of data collection by the research literature (library research) and interview. The results of the research, the impact on the Corruption Eradication Commission (KPK) after the existing Board of Trustees is increased accountability, professionalism and integrity in the implementation of the duties and authority of the Commission. In the annual report found of the Supervisory Board KPK where in the year 2020 the Board of Trustees have been doing Oversight Coordination Meeting to evaluate the implementation of the tasks and authority of the KPK. During the year 2020, the Board of Trustees has received 252 (two hundred fiftytwo) report on the complaint. And then related to the handling of the code of ethics of the Board of Trustees has received reports of as many as 31 (thirty one) reports and a total of 15 (fifteen) reports that followed.

Keywords: The Criminal, KPK And The Board Of Trustees

\section{INTRODUCTION}

National development aims to realize a complete Indonesian man and the people of Indonesia is entirely fair and prosperous, prosperous and orderly based on Pancasila and the constitution of the Republic of Indonesia Year 1945, to create a society of a fair, prosperous and prosperous, need to be continuously improved efforts to 
the prevention and eradication of criminal acts in general and corruption in particular. ${ }^{1}$

Amid the efforts of national development in various fields, the aspirations of the people to eradicate corruption and form other irregularities increases, because in fact an act of corruption has caused the state losses are very large which in turn can have an impact on the onset of the crisis in a variety of fields. For that the prevention and eradication of corruption need to be improved and intensified by upholding human rights and the interests of the community. $^{2}$

In Islamic perspective, the existence of supervision, is one of the branches of amar ma'ruf nahi munkar in politics and matters of the public. The principle of amar ma'ruf nahi munkar which is the purpose of all authority in Islam, as said by Ibn Timiyah: "All authority in Islam is the goal just a amar ma'ruf nahi munkar", essentially ter symbol in the task of supervision of the people who have power means to realize the political participation of the people in all matters of general and also in the law, starting from the obligation to give advice (sincere) where it has been ordered by the Prophet Muhammad in the hadith tradition: "Religion is advice (sincerity) to Allah SWT, to His Messenger and to the leaders of the muslims to all muslims". And the word of God: "If they advice (with sincerity) to Allah and His Messenger" (Q.S. At-Tawbah: 91). ${ }^{3}$

Corruption in Indonesia has been very widespread and has signed up to all layers of society. Its development is steadily increasing from year to year, in the number of cases that occur and the amount of financial loss to the state as well as in terms of the quality of criminal acts of corruption committed more systematic, which has entered all aspects of community life. Should be aware of the increasing corruption of the uncontrolled will impact not only the national economy but also on the life of the nation in general.
Corruption is a threat to democratic principles, uphold transparency, accountability and integrity, as well as the security and stability of the nation of Indonesia. Because corruption is a crime that is systematic and detrimental to sustainable development that require measures of prevention and eradication that is comprehensive, systematic and continuous both at national and international level. In carrying out the prevention and eradication of criminal acts of corruption that are necessary for efficient and effective management support good governance and international cooperation, including the return of assets derived from corruption. ${ }^{4}$

Law enforcement in order for the eradication of criminal acts of corruption committed in the conventional has been proven to experience a variety of barriers. Thus, the necessary method of law enforcement in a remarkable manner through the establishment of a special agency which has broad authority, independent and free from any authority in the effort to eradicate corruption, the implementation is done optimally, intensive, effective, professional and sustainable. ${ }^{5}$

The establishment of institutions to help independent illustrate the need to hand over power during this centralized bureaucracy/government to such institutions. This is as a result of the demands of the development of the management of the state power of an increasingly complex while the organization is bureaucratic, centralized and concentrated can no longer resolve such complexity. Therefore, it appears the need to form an independent state agency to solve the problems of the complex. ${ }^{6}$

Corruption is an extraordinary crime (extra ordinary crime) which requires the eradication efforts in ways that are incredible (extra ordinary measure) then established a special institution, namely the Corruption Eradication Commission (KPK). Formed based on Law No. 30 of 2002 on the Corruption Eradication Commission. In the development of legislation governing 
the Corruption Eradication Commission (KPK) has been converted into Law No. 19 2019 about Changes To Two (2) of Law No. 30 of 2002 on the Corruption Eradication Commission (hereinafter referred to as Act No. 19 2019).

Recent cases of corruption are talking about i.e. cases of corruption social assistance (bansos) Covid-19 involving the minister of social affairs. The Corruption Eradication commission (KPK) will explore the possibility of money flowing into the political party of the proceeds of corruption. The case is dragging the name of the social affairs minister Juliari Peter Batubara. Allegedly received a total of $\mathrm{Rp}$. 17.000.000.000,- (seventeen billion dollars), of two packages of the implementation of the social assistance (social assistance) in the form of groceries for the handling of Covid-19 in the greater Jakarta region by 2020. The number was thought to be the accumulation of the acceptance fee $\mathrm{Rp}$. $10.000,-$ (ten thousand dollars) per food package. Procurement social assistance (bansos) handling of Covid-19 in the form of food packages in the Ministry of Social affairs of the Republic of Indonesia Year 2020 alone has a value of around $\mathrm{Rp}$. 5.900.000.000.000,- (five trillion nine hundred billion rupiah), with a total of 272 (two hundred seventy-two) contracts and implemented two (2) periods. Trimming the fund of social assistance for the handling of Covid-19 in the greater Jakarta region 2020 is allegedly have been designed since the beginning. Based on the information compiled, of the cost of Rp. 300.000,- (three hundred thousand rupiah) issued per food package, there is a margin of Rp.70.000,(seventy thousand dollars) that will be distributed to a number of parties, the owner of the quota of $40 \%$ (forty percent), the creator of $10 \%$ (ten percent) and suppliers $50 \%$ (fifty percent). ${ }^{7}$

The establishment of the Corruption Eradication Commission (KPK) is the mandate of Article 43 of Act No. 31 Year 1999 on Eradication Criminal Acts of Corruption, as amended by Act No. 20 Year
2001 on the amendment of Act No.31 Year 1999 on the Eradication of Criminal Acts of Corruption that are independent with the duty and authority to perform the eradication of criminal acts of corruption. The KPK has a vision to make Indonesia free from corruption and mission of the drivers of change to realize a nation that anti-corruption. The Corruption Eradication commission (KPK) has the task of conducting an investigation, investigation, prosecution of criminal acts of corruption. Understanding the investigator is an investigator at the Commission who are appointed and dismissed by the Commission. Investigators as referred to above is to run the function investigation of criminal acts of corruption. Act No. 30 Year 2002 on the Commission in Article 3 and Article 4 states that "the Commission is a State Agency in carrying out its duties and powers are independent and free from the influence of a general power" in Article 4 of the Commission was formed with the aim of improving the effectiveness and efficiency against the corruption eradication efforts. ${ }^{8}$

Each state agency should be monitored, there should be no state agency that his power is left unattended, then from it the power of a mandatory controlled. The issue is how the surveillance system was built. Power without oversight tends to corrupt while the power with the supervision tends to be easily intervened and led to the ineffectiveness of an institution or power. Before the birth of the Supervisory Board in the Legislation of the Corruption Eradication Commission (KPK) which is new, the Commission already has a system of supervision of the supervision of the internal to external oversight. The internal control system, namely the Ethics Committee for the leadership of the Commission which is set in the Regulations of the Commission No. 7 Years 2013 and the Field of Internal audit for the employees of KPK. While the system of external supervision as institutions of other countries, the financial Commission audited by the supreme audit Agency (BPK) and the 
issue of wiretapping has also supervised by the Ministry of Communication and Information technology. ${ }^{9}$

Politically also the Corruption Eradication Commission (KPK) to report its performance to the people through the People's Representative Council (DPR) especially regarding the performance of KPK which is not associated with the case law of concrete addresses. Because ideally, the institutions that control the performance of the handling of the case the Commission is the institution of the judiciary. The judiciary has also become of external monitoring institution that has control against the work of the Commission. All the performance of law enforcement conducted the Commission has the appropriate function control by the judiciary. All the authority of law enforcement that are forced sort of tapping, pengeledahan and seizure conducted by first obtaining the permission of the Court. ${ }^{10}$

The Enactment Of Law No. 19-Year 2019, there are many conflicts that into a debate with any changes to the substance of the law. One of the changes to the Law No. 19-Year 2019, requires the establishment of a Board of Trustees. The board of Trustees was formed in order to carry out its function is to supervise the implementation of the duties and authority of the Corruption Eradication Commission (KPK) as stated in Article 37 of A paragraph (1) of Law No. 19 2019. In Article 37 B Of Law No. 19-Year 2019, we mentioned in detail about the tasks of the Supervisory Board is to supervise the implementation of the duties and authority of the KPK as well as, give permission or not to give permission tapping, shakedown, and/or seizure, develop and establish the code of ethics of the leadership and employees of the Commission, receive and act on reports from the community about the existence of the alleged violations of the code of ethics by leaders and employees of the Commission or a violation of the provisions in this law, held a hearing to examine the alleged violations of the code of ethics by leaders and employees of the
Commission and conduct a performance evaluation of the leadership and employees of the Commission periodically one time in one (1) year. In the article show that the Supervisory Board perform settings on the implementation of actions carried out by the Commission and has the function of Pro Justitia. ${ }^{11}$

Act No. 30 of 2002 on the Corruption Eradication Commission, as amended by Act No. 19 Years 2019 on the Corruption Eradication Commission presented the Board of Trustees will control and supervise the performance of the Commission for the Eradication of Criminal Acts of Corruption. This law is registered in the State gazette No. 197 2019. Some of the provisions in Legislation No. 30 of 2002 on the Corruption Eradication Commission changes, insertion and removal are loaded on the Law No. 192019 about the same thing. The provisions of Article 3 of Law No. 30 of 2002, amended by Law No. 19Year 2019 by adding the words "in the groves of the executive power" so that it reads, the Corruption Eradication Commission (KPK) is "state institutions in a clump of executive power in carrying out its duties and powers are independent and free from the influence of any authority".

Based on the explanation of the Law No. 19-Year 2019, which indicates it supports the existence of the Supervisory Board because it required the renewal of the legal order in the prevention and eradication of criminal acts of corruption runs with the effective and integrated. The establishment of the Supervisory Board is to supervise and control the execution of the duties and authority of the Corruption Eradication Commission (KPK) so that it can reduce the abuse of authority. ${ }^{12}$

Law reform in the law governing the Corruption Eradication Commission (KPK), where the set of actions to be performed by the Commission for the prevention and eradication in corruption should be based on the permit of the Supervisory Board in cooperation with the Commission in carrying out the task in the prevention and 
eradication of criminal acts of corruption and to see the independence of the Supervisory Board in KPK in Indonesia to realize the Indonesian society that is fair, and prosperous in accordance with the mandate of the constitution of the Republic of Indonesia Year 1945.

Based on the basic thoughts as has been described previously, then that becomes the background of why this research is important to be done is to determine the role of the Board of Trustees of the Corruption Eradication Commission (KPK) in the process of law enforcement against criminal acts of corruption as well as view the legal position of the Supervisory Board of the Commission in granting permission related to wiretapping, search and seizure conducted by the Commission in the prevention and eradication of corruption in Indonesia.

\section{MATERIAL AND METHODS}

Methods of research seeks to explain the entire network of activities that will be done in the framework of answering point or prove the assumption that submitted to be found, developed, or demonstrated, a certain knowledge until in turn can be used to understand, break down and to anticipate the problem in a particular field.13 To answer the crux of the problem and prove the assumption should be didikung by the facts and the results of the research. This research is research of the law of the normative with the approach of legislation (statute approach) in doing research using the technique of data collection with research kepustakaan (library research) and interview.

\section{RESULTS AND DISCUSSION}

The role of the Board of Trustees of the Corruption Eradication Commission (KPK) In the Enforcement of the Law Against Corruption

The board of Trustees in conducting prevention and eradication of criminal acts of corruption has a role and authority as a concept of public law at least consists of 3 (three) elements as follows:

1. The effect is that the use of authority is intended to control the behavior of the subject of law.

2. The legal basis that the authority it can always be shown the basic law.

3. Conformity implies the existence of a standard authority, namely the general standard (all kinds of authority) and standard special (for the type of authority specific). ${ }^{14}$

Based on the view of the foregoing, it can be concluded that the authority is a right held by an official or government or institutions that run the authority repose on the laws and regulations that apply.

The form of the capacity of the authority of the Board of Trustees of law enforcement corruption in the prevention and eradication of corruption contained in the provisions of Law No. 19 Years 2019 on Second amendment (2) of Law No. 30 of 2002 on the Corruption Eradication Commission (KPK), Article 37 B. The board of Trustees on duty:

1. The board of Trustees on duty:

a. Oversee the implementation of the duties and authority of the Corruption Eradication Commission;

b. Give permission or not to give permission Wiretaps, searches, and/or seizure;

c. Develop and establish the code of ethics of the Leadership and Employees of the Commission on Combating Corruption;

d. Receive and act on reports from the community about the existence of the alleged violations of the code of ethics by Leaders and Employees of the Commission on the Eradication of Corruption or violation of the provisions in this Law;

e. Held a hearing to examine the alleged violations of the code of ethics by Leaders and Employees of the Corruption Eradication Commission; and 
f. Conduct performance evaluation of the Chairman and Clerk of the Corruption Eradication Commission periodically of 1 (one) times in 1 (one) year.

2. The Supervisory board made a report on the implementation of the task periodically 1 (one) times in 1 (one) year.

3. The report referred to in paragraph (2) shall be submitted to the President of the Republic of Indonesia and the People's Representative Council of the Republic of Indonesia. ${ }^{15}$

The verdict of things Constitutional Court No. 70/PUU-XVII/2019 performed by the Applicant Fathul Wahid, dkk., Assembly of Judges of Constitutional Court of the Republic of Indonesia granted the request of the Applicants for the part. Accepted this application in particular about some of the authority of the board of Overseers from Corruption Eradication Commission (KPK) disconnected do not have the law of binding and do not have the law binding in the conditional.

The authority of the board of Overseers from Corruption Eradication Commission (KPK) the provisions of Law No. The 19-Year 2019 about the Change of the Second (2) on the Law No. 30 Year 2002 on from Corruption Eradication Commission (KPK) that changed postJudgment of Constitutional Court of the Republic of Indonesia No. 70/PUUXVII/2019, as follows:

1. Stating Article 12 B, Article 37 B paragraph (1) letter b, and Article 47 paragraph (2) contrary to the Law Of the National Policy of the Republic of Indonesia Year 1945 and did not have the strength of the law of binding. The provisions in this article are about the permission of the wiretaps, search, and/or seizure, in which the Constitutional Court of the Republic of Indonesia considers that the position of the board of Overseers is not in the nature of the hierarchy with the Command from Corruption Eradication
Commission (KPK) up in great design eradication of corruption both are not mutually under yet mutually synergistic in carrying out their respective functions.

Constitutional court of the Republic of Indonesia also argues in the country the law of which is indeed not possible availability of intervention in the form of anything against the institutions of the law, including in it not can there is a board of the nature of the extralegal/extra judicial given the authority of the judicial/pro Justitia, because the existence of the board of the nature of extra-legal by the authority that such a threat for independensi law enforcement agencies, which in the end can undermine the existence of the principle of national law. Based on the case, the Constitutional Court of the Republic of Indonesia expressed the action of tapping the done Command of the KPK does not require permission from the board of Regents but enough with to tell the board of Overseers. ${ }^{16}$

2. Stating the phrase "accountable to the Supervisory Board" in Section 12 C of paragraph (2) contrary to the constitution of the Republic of Indonesia Year 1945 and does not have the binding force of law is conditional to the extent not defined "is notified to the Board of Trustees".

Section 12 C of paragraph (2) that originally reads :

"Tapping as referred to in Article 12 paragraph (1) that has been completed must be accountable to the Leaders of the Corruption Eradication Commission (KPK) and the Board of Trustees no later than 14 (fourteen) working days from the tapping done".

Section $12 \mathrm{C}$ of paragraph (2) which became reads:

"Tapping as referred to in Article 12 paragraph (1) that has been completed must be accountable to the Leaders of the Corruption Eradication Commission (KPK) and notified to the Board of 
Trustees no later than 14 (fourteen) working days from the tapping done". ${ }^{17}$

3. Stating the phrase "must be reported to the Board of Trustees no later than 1 (one) week" in Article 40 paragraph (2) contrary to the constitution of the Republic of Indonesia Year 1945 and does not have binding legal force to the extent not defined "is notified to the Board of Trustees no later than 14 (fourteen) working days".

Article 40 paragraph (2) that originally reads :

"The termination of investigations and prosecutions referred to in paragraph (1) must be reported to the Board of Trustees no later than 1 (one) week commencing from the issuance of the warrant termination of the investigation and prosecution".

Article 40 paragraph (2) which became reads :

"The termination of investigations and prosecutions referred to in paragraph (1) shall be notified to the Board of Trustees no later than 14 (fourteen) working days since the issuance of the warrant termination of the investigation and prosecution".

4. Stating the phrase "over the prior written permission of the Board of Trustees" in Article 47 paragraph (1) is contrary to the constitution of the Republic of Indonesia Year 1945 and does not have binding legal force throughout not interpreted "by notifying the Board of Trustees".

Article 47 paragraph (1) original sound : "In the process of the investigation, the investigator can perform a search warrant and the seizure of over the prior written permission of the Board of Trustees".

Article 47 paragraph (1) which is becoming more reads:

"In the process of the investigation, the investigator can perform a search and seizure by notifying the Board of Trustees". 18
At least in the judgment of the Constitutional Court of the Republic of Indonesia, there are 4 (four) the provisions of the change relating to the Board of Trustees of the Corruption Eradication Commission (KPK). That the position of the ruling of the Constitutional Court of the Republic of Indonesia based on Article 10 paragraph (1) of Law No. 24, 2003 on the Constitutional Court of the Republic of Indonesia is final and binding, so there is no other remedy that can be taken, then of course change this rule must be implemented and made changes so in accordance with the provisions on the decision of the Constitutional Court of the Republic of Indonesia.

The form of the capacity of the Supervisory Board of law enforcement corruption one of them in the form of supervision in essence directed fully to avoid any loopholes to commit fraud or irregularities on the objectives to be achieved. Through surveillance is also expected to facilitate carrying out the policy that has been set effectively and efficiently. So, through the supervision created an activity which is closely related to the determination or evaluation of the extent to which the implementation of the work has been carried out. Supervision can also assess the extent to which the policy of the leadership of the run and to what extent the deviations that occur in the execution of such work. ${ }^{19}$

In fact, based on Article 1 paragraph (3) Basic law the Republic of Indonesia Year 1945 Mentioned that Indonesia is a country of laws. The concept of the state law is understood as a philosophy or political theory that determines the number of fundamental reasons against the law, or as a means of procedural needed by those who ruled under the law and in the country there are laws of separation of powers which can be divided into several aspects. According To G. Marshall in his Constitutional Theory there is a "differentiation, legal incompatibility of office holding, isolation or immunity or 
independence, checks and balances, and coordinate status and lack of accountability".

Aspects of check and balances is an aspect which has not been found in the organs of the Corruption Eradication Commission (KPK) and is expected to offset the authority of the organization which is too high/strong. With the presence of the Supervisory Board, is expected to prevent arbitrariness or abuse of power made by the Commission. ${ }^{20}$

The theory of law enforcement that is used in answering the formulation of this problem is the attempt to realize those ideas into reality in order to maximize the role and capacity of institutions in the effort to eradicate corruption through the prevention and prosecution. The board of trustees in the role and the authority has also collaborated with the Corruption Eradication Commission (KPK) to always give permission no later than 1X24 hours (one times twenty-four hours) after receiving a petition in the wiretapping, search and seizure. The effort is intended in the process of the recovery of state assets and areas related to the prevention and eradication of criminal acts of corruption. ${ }^{21}$

\section{The Position Of The Supervisory Board} In Granting Permission Related To Wiretapping, Search And Seizure In The Institutions of The Corruption Eradication Commission (KPK) On The Prevention And Eradication Of Criminal Acts Of Corruption After The Decision Of The Constitutional Court No. 70/PuuXvii/2019
The role and function of the Corruption Eradication Commission (KPK) to monitor and crack down on all forms of corruption is part of the reason that corruption is a common enemy for the state in organizing government so that it can realize good governance. The authority of the Corruption Eradication Commission (KPK) in combating corruption is not only related to wiretapping and blocking course. The foreclosure process and search warrant in order to search for additional evidence related to an event of corruption in fact the authority of the whole of the Commission at the time the law Commission has not undergone a change such as this present moment.

The authority of the Corruption Eradication Commission (KPK) in combating corruption is not only related to wiretapping and blocking course. The foreclosure process and search warrant in order to search for additional evidence related to an event of corruption in fact the authority of the whole of the Commission at the time the law Commission has not undergone a change such as this present moment.

This time after the issuance of the Law of the Republic of Indonesia No. 19 Years 2019 on Second amendment (2) of Law No. 30 of 2002 on the Corruption Eradication Commission (KPK), in terms of the handling of corruption by the corruption eradication Commission has undergone changes in a systematic way, especially related to the process of inquiry, investigation and prosecution of criminal acts of corruption. These comparisons can be seen in the table below:

\begin{tabular}{|l|l|l|l|l|}
\hline NO & \multicolumn{1}{|c|}{ SUBJECT } & \multicolumn{1}{|c|}{ BEFORE } & \multicolumn{1}{c|}{ AFTER } & \multicolumn{1}{c|}{ DESCRIPTION } \\
\hline 1 & $\begin{array}{l}\text { The position of } \\
\text { KPK }\end{array}$ & $\begin{array}{l}\text { The Commission is a } \\
\text { state agency in carrying } \\
\text { out its duties and powers } \\
\text { are independent and free } \\
\text { from the influence of } \\
\text { power anywhere }\end{array}$ & $\begin{array}{l}\text { The Commission a state } \\
\text { agency in a clump of } \\
\text { executive power in } \\
\text { carrying out its duties and } \\
\text { powers are independent } \\
\text { and free from the } \\
\text { influence of power } \\
\text { anywhere }\end{array}$ & $\begin{array}{l}\text { Because the Commission became part } \\
\text { of executive agencies then it is the } \\
\text { authority of the president as head of } \\
\text { government to form the Board of } \\
\text { Trustees }\end{array}$ \\
\hline 2 & $\begin{array}{l}\text { The arrangement } \\
\text { of the } \\
\text { Institutional } \\
\text { KPK }\end{array}$ & $\begin{array}{l}\text { There are a team of } \\
\text { advisors consists of four } \\
\text { (4) members of the }\end{array}$ & $\begin{array}{l}\text { The inclusion of the } \\
\text { Supervisory Board that } \\
\text { consists of five (5) people }\end{array}$ & $\begin{array}{l}\text { The loss of provisions regarding the } \\
\text { existence of the advisory team, then } \\
\text { removed }\end{array}$ \\
\hline
\end{tabular}


Sahri et.al. Criminal law policy related to the role of the supervisory board in the review of legislation no. 19 2019 about changes to two (2) of law no. 30 of 2002 on the corruption eradication commission (KPK).

\begin{tabular}{|c|c|c|c|c|}
\hline \multicolumn{5}{|c|}{ Table Continued... } \\
\hline 3 & $\begin{array}{l}\text { The task of the } \\
\text { Leadership of } \\
\text { the Commission }\end{array}$ & $\begin{array}{l}\text { The leadership of the } \\
\text { Commission is the } \\
\text { investigator and public } \\
\text { prosecutor }\end{array}$ & $\begin{array}{l}\text { KPK leadership is } \\
\text { collective collegial }\end{array}$ & $\begin{array}{l}\text { Article } 21 \text { paragraph (4) is related to } \\
\text { the status of leadership of the } \\
\text { Commission and the public prosecutor } \\
\text { dispensed. This can mean that the } \\
\text { status of leadership of the Commission } \\
\text { serves as the administrative course }\end{array}$ \\
\hline 4 & Person in charge & $\begin{array}{l}\text { The leadership of the } \\
\text { Commission } \\
\text { responsible for the } \\
\text { highest }\end{array}$ & Removed & $\begin{array}{l}\text { The mandate to carry out the highest } \\
\text { responsibility by the leadership of the } \\
\text { Commission deleted after the change }\end{array}$ \\
\hline 5 & $\begin{array}{l}\text { Board } \\
\text { Trustees }\end{array}$ & - & $\begin{array}{l}\text { In between the Article } 37 \\
\text { and Article } 38 \text { of the } \\
\text { pasted } 7 \text { (seven) Article, } \\
\text { namely Article } 37 \text { A, } \\
\text { Section 37B, Chapter 37C, } \\
\text { Section 37D, Section 37E, } \\
\text { Section 37F, and of } \\
\text { Article 37G }\end{array}$ & $\begin{array}{l}\text { In the changes UU KPK formed the } \\
\text { board of regents to oversee the } \\
\text { implementation of tasks and authority } \\
\text { KPK }\end{array}$ \\
\hline 6 & Rule Tapping & - & $\begin{array}{l}\text { Wiretaps performed after } \\
\text { obtaining written } \\
\text { permission from the board } \\
\text { of regents }\end{array}$ & $\begin{array}{l}\text { Permission obtained on the basis of a } \\
\text { request in writing from the leadership } \\
\text { of KPK }\end{array}$ \\
\hline 7 & The inquest & $\begin{array}{l}\text { On the basis of the } \\
\text { conjecture that strong } \\
\text { evidence enough, the } \\
\text { Investigator can do the } \\
\text { foreclosure without the } \\
\text { permission of the } \\
\text { Chairman of the district } \\
\text { Court relating to the } \\
\text { tasks of their } \\
\text { investigation }\end{array}$ & $\begin{array}{l}\text { In the process of } \\
\text { investigation, } \\
\text { penyidikdapat } \\
\text { penggeledahaan and the } \\
\text { seizure of over the prior } \\
\text { written permission of the } \\
\text { Board of Trustees }\end{array}$ & $\begin{array}{l}\text { The board of Trustees here. to give } \\
\text { permission or not to give permission at } \\
\text { the most } 1 \times 24 \text { hours since the request is } \\
\text { submitted. With this it can be } \\
\text { concluded in accordance with the } \\
\text { authority in Article } 37 \mathrm{~B} \text { paragraph (1) } \\
\text { letter b, can the Supervisory Board did } \\
\text { not give permission. }\end{array}$ \\
\hline
\end{tabular}

The Discharge Of The Government Regulation No. 42020 about procedures for the Appointment of the Chairman and members of the Supervisory Board of the Corruption Eradication Commission (KPK) further strengthens the position against the existence of the Board of Trustees in the body of the KPK itself. The chairman and the Supervisory Board of the Commission appointed and designated by the President in accordance with Article 4, paragraph 1 of the ordinance of the Appointment of the Chairman and members of the Supervisory Board of the Corruption Eradication Commission (KPK) Government Regulation No. 42020.

Then from the position of the Supervisory Board as a kind of oversight in this case, extend the line of the bureaucracy in the handling of criminal cases of corruption and the terms will be intervention to cases handled by the Corruption Eradication Commission (KPK) because it is associated with the branches of the other powers, namely the executive. Therefore, to make the process of forced (wiretapping, search and/or seizure) is hung on the instrument permits under the authority of the Board of Trustees.

The legal status of the Board of Trustees of the Corruption Eradication Commission has the task of one of these is to give permission or not to give permission wiretapping, search and/or seizure contained in article 37 B letter b of Law of the Republic of Indonesia No. 19 Years 2019 on Second amendment (2) of Law No. 30 of 2002 on the Corruption Eradication Commission (KPK). In the legislation of the mechanism of granting permission spelled out in general terms. The board of Trustees of the Corruption Eradication

Commission (KPK) is regulated in Chapter VA of Article 37 A to Article 37 G of which set about the purpose of the formation, the task, the organ of the committee, the terms of a member, the process of selection and appointment, the 
mechanism of termination and the oath of office.

About the position the duties of the Supervisory Board is regulated in Article 37 B the Law of the Republic of Indonesia No. 19 Years 2019 on Second amendment (2) of Law No. 30 of 2002 on the Corruption Eradication Commission (KPK). The board of Trustees in performing the tasks referred to in Article $37 \mathrm{~B}$ forming organs executor trustees. The provisions of the organs of executive supervisors referred governed by Presidential decree No. 912019 about the Organs of the Executive of the Board of Trustees of the Corruption Eradication Commission.

After done changes to the Legislation of the Republic of Indonesia No. 19 Years 2019 on Second amendment (2) of Law No. 30 of 2002 on the Corruption Eradication Commission (KPK), the process to obtain a permit wiretapping, search and seizure must go through the Board of Trustees as written in Article 12 B, paragraph 1 and paragraph 4, as follows:

1. Tapping as referred to in Article 12, Paragraph 1, conducted after obtaining written permission from the Board of Trustees.

2. To obtain a permit as referred to in paragraph 1 is implemented based on a written request from the Chairman of the Corruption Eradication Commission.

3. The Supervisory board may give written permission to the request referred to in paragraph 2 of the most long-1 X 24 (one times twenty-four) hours since the request was filed.

4. In the case of the Leaders of the Corruption Eradication Commission to obtain written permission from the Supervisory Board as referred to in paragraph 3 , the tapping is done at most 6 (six) months since the prior written permission received and can be extended for 1 (one) time for the same period of time. ${ }^{22}$

Under these provisions, it is clear that refers to the enactment of the Legislation of the Republic of Indonesia No.
19 Years 2019 on Second amendment (2) of Law No. 30 of 2002 on the Corruption Eradication Commission (KPK), in particular regarding the authority of the Board of Trustees, any action related to the effort of tapping, search warrant to foreclosure that will do the Commission in handling cases of corruption mandatory and must be approved by the Board of Trustees in order to get legal certainty for the actions carried out based on the rules of the provisions of these articles. ${ }^{23}$

If then the Corruption Eradication Commission (KPK) do the wiretapping, search and seizure in the absence of the consent of the Supervisory Board, then such actions are contrary to the law and can be classified as an act against the law. Such action can also cause the emptiness of the law in execution, much less held to the agency and/or the office of community organizations and offices of political parties as well as other legal entities that have the authority to private by the owner to determine the access and the actions that can be done in the region where such rights are attached. Even the above actions are also prone to pose the matter in the form of a lawsuit and/or reporting personally against individual KPK investigators are still sustain the process of wiretapping, search and seizure without the permission of the Board of Trustees.

or specific rules regarding the basics or criteria that influence the Board of Trustees to give or not give permission wiretapping, search and seizure only found in the internal regulations of the Corruption Eradication Commission (KPK). With the entry into force of the Legislation of the Republic of Indonesia No. 19 Years 2019 on Second amendment (2) of Law No. 30 of 2002 on the Corruption Eradication Commission (KPK), wiretapping, search and seizure must obtain written permission from the Board of Trustees where to get such permission should be implemented based on a written request from the Leadership of the Commission not previously need to get such permission. It is 
intended to prevent the action of the highhandedness so it gives the strengthening of Human Rights (HAM) and keeping accountability in tap, frisk and seizure. ${ }^{24}$

After The Decision Of The Constitutional Court Of The Republic Of Indonesia No. 70/PUU-XVII/2019, accepted as of the petition on the test material makes the means of control for the Government and the People's Representative Council (DPR) as the framer of the law is still running, so the terms are formed not in conflict with the constitution of the Republic of Indonesia Year 1945. The authority of the Constitutional Court of the Republic of Indonesia is also can be as a means of participation for the people mainly affected by any provision in a rule in the law that have been published, to get the container to convey the loss of those terms.

The position of the independence of the Corruption Eradication Commission (KPK) look is accentuated by the Constitutional Court of the Republic of Indonesia. The board of Trustees as a part in the body of the Commission, does not have the authority pro justisia, so that the Constitutional Court of the Republic of Indonesia separate relations pro justisia in KPK with the Supervisory Board of the Commission to the extent notice of the execution of tasks and supervision over the behavior of employees and the leadership of the Commission, not as a breaker direction of the actions carried out by the Commission. ${ }^{25}$

The theory of legal certainty in the answer to this problem is the point in this section is questioning the authority of the Board of Trustees to grant permission or not to give permission wiretapping, search and/or seizure. This concept is a fallacy which is fundamental in the thought pattern forming the legislation. The consequences that would arise, namely the process of prosecution of criminal acts of corruption committed by the Corruption Eradication Commission (KPK) will slow down.

The existence of the Supervisory Board is regulated in the Legislation of the
Republic of Indonesia No. 19 Years 2019 on Second amendment (2) of Law No. 30 of 2002 on the Corruption Eradication Commission (KPK), based on the function and authority indeed not thoroughly can be said to be an obstacle to the Commission in carrying out the functions and duties of enforcing the law. It is also seen from the situation that occurred during this time, where the Commission as an institution of the state equivalent of the executive considered to have the power and authority of the excess in the absence of any one institution or agency authorized to oversee the KPK during the run of functions and duties. It is necessary to the renewal of the law Commission which is now enacted, the existence of the Board of Trustees considered important based on the function and authority in the structure of institutional Commission at this time.

\section{CONCLUSIONS}

The role and function of the Corruption Eradication Commission (KPK) to monitor and crack down on all forms of corruption is part of the reason that corruption is a common enemy for the state in organizing government so that it can realize good governance and the actual. The functions and duties of the Board of Trustees over its presence in the institutional structure of the Corruption Eradication Commission (KPK) is to run the function of supervision over the implementation of the duties and powers of the Commission itself in the future. Please also note who later became a member of the Supervisory Board is in the part of the institutional structure of the Commission in carrying out its duties. Shape the role of the Board of Trustees of law enforcement corruption one of them in the form of supervision in essence directed fully to avoid any loopholes to commit fraud or irregularities on the objectives to be achieved. Through surveillance is also expected to facilitate carrying out the policy that has been set effectively and efficiently. So, through the supervision created an activity which is closely related to the 
determination or evaluation of the extent to which the implementation of the work has been carried out. Supervision can also assess the extent to which the policy of the leadership of the run and to what extent the deviations that occur in the execution of such work. In terms of the handling of corruption by the Corruption Eradication Commission (KPK) has undergone changes in a systematic way, especially related to the process of inquiry, investigation and prosecution of criminal acts of corruption. In the end the view of what then of the form of the Board of Trustees as intended in the Legislation of the Republic of Indonesia No. 19 Years 2019 on Second amendment (2) of Law No. 30 of 2002 on the Corruption Eradication Commission (KPK). The position of the Supervisory Board in the institutional structure of the Commission are currently regulated in Chapter VA of the Legislation of the Republic of Indonesia No. 19 Years 2019 on Second amendment (2) of Law No. 30 of 2002 on the Corruption Eradication Commission (KPK). Such a rule which later became the legal basis for the existence of the Supervisory Board in the institutional structure of the Commission that there is now this. The legal status of the Board of Trustees of the Corruption Eradication Commission has the task of one of these is to give permission or not to give permission wiretapping, search and/or seizure contained in article $37 \mathrm{~B}$ letter $\mathrm{b}$ of Law of the Republic of Indonesia No. 19 Years 2019 on Second amendment (2) of Law No. 30 of 2002 on the Corruption Eradication Commission (KPK). In the legislation of the mechanism of granting permission spelled out in general terms. The board of Trustees of the Corruption Eradication Commission (KPK) is regulated in Chapter VA of Article 37 A to Article 37 $\mathrm{G}$ of which set about the purpose of the formation, the task, the organ of the committee, the terms of a member, the process of selection and appointment, the mechanism of termination and the oath of office.
It should be in one of the functions of the Corruption Eradication Commission (KPK) in the prevention and eradication of criminal acts of corruption the role of the Board of Trustees of the form of supervision in essence directed fully to avoid any loopholes to commit fraud or irregularities in the process of enforcement of such laws. In addition, should the legal position of the Supervisory Board on the provisions of the Legislation of the Republic of Indonesia No. 19 Years 2019 on Second amendment (2) of Law No. 30 of 2002 on the Corruption Eradication Commission (KPK), for specific rules regarding the basics or criteria that influence the Board of Trustees to found in the internal regulations of the Commission, but presumably contained in the provisions of the regulations.

\section{Acknowledgement: None}

\section{Conflict of Interest: None}

\section{Source of Funding: None}

\section{REFERENCES}

1. Ermansjah Djaja, Memberantas Korupsi Bersama Komisi Pemberantasan Korupsi $(K P K)$, Jakarta: Sinar Grafika, 2008, hlm: 24

2. Ni'matul Huda, Problematika Pembatalan Peraturan Daerah, Yogyakarta: FH UII Press, 2010, hlm: 48.

3. Ancok D., Korupsi: Sekelumit Visi Psikologi Terapan, Yogyakarta: Unsrat, 2017, hlm: 11

4. Ian Mc Walters, Memerangi Korupsi: Sebuah Peta Jalan Untuk Indonesia, Surabaya: PT. Tempira Media Grafika, 2006, hlm: 9.

5. Ismail Aris, Kedudukan Komisi Pemberantasan Korupsi (KPK) Dalam Sistem Ketatanegaraan Dalam Perspektif Teori The New Separation of Power, Jakarta: Jurisprudentie No. 1, 2018, hlm: 102.

6. Brigita Oktavia W, Universitas Widya Mandala Surabaya, Kasus Korupsi Bantuan Sosial Covid-19 Melibatkan Menteri Sosial Republik Indonesia, Melalui: 
https://journal.osf.io/cdujz, diakses Tanggal 20 Februari 2021, Pukul 13:20 WIB.

7. Muhamad Yusuf, Ikhtisar Ketentuan Pencegahan dan Pemberantasan Tindak Pidana Pencucian Uang, Jakarta: NLRP, 2010, hlm: 547-549.

8. Indriyanto Seno Adji, Pengujian Oleh Publik (Public Review) Terhadap Rancangan Undang-Undang Tentang Komisi Pemberantasan Tindak Pidana Korupsi, Jakarta: Indonesia Corruption Watch, 2016, hlm: 139.

9. Cris Septiani, Universitas Airlangga, Dewan Pengawas Dalam Undang-Undang No. 19 Tahun 2019 tentang Perubahan Ke Dua (2) atas Undang-Undang No. 30 Tahun 2002, Melalui:

http://repository.unair.ac.id/102630/, diakses Tanggal 20 Februari 2021, Pukul 08:15 WIB.

10. Cris Septiani, Universitas Airlangga, Dewan Pengawas Dalam Undang-Undang No. 19 Tahun 2019 tentang Perubahan Ke Dua (2) atas Undang-Undang No. 30 Tahun 2002.

11. Yoga Winando, Tujuan Metode Penelitian, Melalui:

https://www.ejournalgurupendidikan.co.id/ metodologi-penelitian/, diakses Tanggal 6 April 2021, Pukul 11:15 WIB.

12. Nur Basuki Winarno, Penyalahgunaan Wewenang dan Tindak Pidana Korupsi, Yogyakarta: Laksbang Media Tama, 2008, hlm: 65

13. Pasal 37 B Undang-Undang Republik Indonesia No. 19 Tahun 2019 tentang Perubahan Kedua (2) atas Undang-Undang No. 30 Tahun 2002 tentang Komisi Pemberantasan Korupsi (KPK).

14. Riyo Eka Sahputra, Pergeseran Tugas Dewan Pengawas Komisi Pemberantasan Korupsi (KPK) Usai Terbitnya Putusan MK No. $\quad 70 / P U U-X V I I / 2019, \quad$ Melalui: https://kumparan.com/riyoekasahputra/perg eseran-tugas-dewas-kpk-usai-terbitnyaputusan-mk-no-70-puu-xvii-2019-

1vgWUSoBLrD/full, diakses Tanggal 19 Agustus 2021, Pukul 07:30 WIB.

15. Riyo Eka Sahputra, Pergeseran Tugas Dewan Pengawas Komisi Pemberantasan Korupsi (KPK) Usai Terbitnya Putusan MK No. 70/PUU-XVII/2019.
16. Riyo Eka Sahputra, Pergeseran Tugas Dewan Pengawas Komisi Pemberantasan Korupsi (KPK) Usai Terbitnya Putusan MK No. 70/PUU-XVII/2019.

17. Jazim Hamidi \& Mustafa Lutfi, Dekontruksi Hukum Pengawasan Daerah, Malang: UB Press, 2011, hlm: 112

18. Komisi Pemberantasan Korupsi (KPK), Biro Hubungan Masyarakat, Latarbelakang Dibentuknya Dewan Pengawas, Laporan Hasil Penelitian Tesis No. 2.

19. Tumpak Hatorangan (Ketua Dewas) Komisi Pemberantasan Korupsi (KPK), Laporan Kinerja, $\quad$ Melalui: https://www.kpk.go.id/id/berita/siaranpers/1781 laporan kinerja kpk semester 1 tahun 2020, diakses Tanggal 8 Mei 2021, Pukul 10:15 WIB.

20. Hafiz Maulana Akbar, Universitas Islam Kalimantan, Analisi Penyadapan, Penggeledahan dan Penyitaan Dalam Operasi Tangkap Tangan Oleh Komisi Pemberantasan Korupsi (KPK), Melalui: http://ejournal.eprints.uniska-

bjm.ac.id/3028/, diakses Tanggal 27 Mei 2021, Pukul 11:15 WIB.

21. Hafiz Maulana Akbar, Universitas Islam Kalimantan, Analisi Penyadapan, Penggeledahan dan Penyitaan Dalam Operasi Tangkap Tangan Oleh Komisi Pemberantasan Korupsi (KPK).

22. Hafiz Maulana Akbar, Universitas Islam Kalimantan, Analisi Penyadapan, Penggeledahan dan Penyitaan Dalam Operasi Tangkap Tangan Oleh Komisi Pemberantasan Korupsi (KPK).

23. Riyo Eka Sahputra, Pergeseran Tugas Dewan Pengawas Komisi Pemberantasan Korupsi (KPK) Usai Terbitnya Putusan MK No. 70/PUU-XVII/2019. Op.Cit.

How to cite this article: Sahri, Mahmud Mulyadi, Dedi Harianto. Criminal law policy related to the role of the supervisory board in the review of legislation no. 192019 about changes to two (2) of law no. 30 of 2002 on the corruption eradication commission (KPK). International Journal of Research and Review. 2022; 9(2): 315-327. DOI: https://doi.org/10. 52403/ijrr.20220242 